\title{
America, Defender of Democratic Legitimacy?
}

\author{
James C. Hathaway*
}

\begin{abstract}
American exceptionalism - a belief that the United States has a unique mission to lead the world, but ought logically to be exempt from the rules it promotes - is at the root of much of the American academy's effort to rationalize the US government's increasing rejection of multilateralism as the cornerstone of modern public international law. Even American scholars who disagree fundamentally on the problems with multilateralism (Kenneth Anderson arguing that it favours anti-democratic intervention by unelected NGOs, Michael Reisman asserting that it privileges elitist state-based lawmaking in the face of more democratic non-state 'lawmaking' processes) can agree on the solution: more unilateralism by powerful states, particularly by the United States. In this critique, James Hathaway contends that the amorphous law-as-policy depictions of the problems with multilateralism disguise a determination to equate valid international law with the priorities of powerful states, and that the presumed solution of American unilateralism reflects a mistaken belief that the United States can be assumed always to operate on the basis of principle-derived autopilot.
\end{abstract}

There is a restlessness in much of the American academy with the central place afforded multilateralism in modern public international law. The assault on multilateralism may be framed boldly, as in Allan Gerson's unapologetic assertion of the right of powerful states to invoke political concerns to trump formal legal commitments. ${ }^{1}$ It may also be framed as a studiously earnest call to reconsider the virtues of unilaterialism, as exemplified by José Alvarez's feigned disbelief that international lawyers could for so long have been unthinking participants in a 'semi-religious crusade on behalf of internationalist agendas'. ${ }^{2}$ Neither of these approaches seems to me to be a helpful means of coming to grips with the real dilemma

* Professor of Law, The University of Michigan. The research assistance of William Johnson and the research support of the William W. Cook Endowment are gratefully acknowledged. José Alvarez, Christine Chinkin, Catharine MacKinnon and Eric Stein kindly read and commented on an earlier draft; none, however, bears any responsibility for the analysis presented here.

1 See Gerson, this issue.

2 J. Alvarez, 'Multilateralism and its Discontents', 11 EJIL (2000), forthcoming. Most of Alvarez's piece is devoted to making a simple and uncontroversial point, namely that multilateralism is not an unmitigated good. He sets up several artificial assumptions to justify an abstract, tabula rasa inquiry into the failings of multilateralism. His argument is that international lawyers unthinkingly '.. worship at the shrine of global institutions like the UN'. But since '. . . our most ambitious multilateral projects have repeatedly

EJIL (2000), Vol. 11 No. 1, 121-134 
that confronts us today, namely the increasing propensity of powerful states to withdraw, formally or in practice, from the multilateral legal enterprise. In contrast, two participants in this symposium, Kenneth Anderson and Michael Reisman, have endeavoured to provide a systematic and contextualized academic justification for the shift towards unilateralism.

Anderson examines the history of the negotiation of the Treaty on Anti-Personnel Mines ${ }^{3}$ in search of an explanation for the resistance of the United States to sign-on to the final accord. ${ }^{4}$ His thesis, in brief, is that because true international law has been supplanted by fundamentally undemocratic modes of supranational lawmaking, countries such as the United States are justified in withholding their consent to be bound by suspect multilateral regimes. This is so even when, as in the case of the Treaty on Anti-Personnel Mines, the goals advanced are of critical importance to the world community.

Michael Reisman's focus is the validity of unilateral action in the face of conflicting formal multilateral commitments. ${ }^{5}$ After carefully setting out a framework for determining when unilateral international acts are legally valid, Reisman opines that because the formal Charter-based mechanism for ordering humanitarian intervention to protect human rights is dysfunctional, unilateral intervention sanctioned by an amorphous constitutive process meets the requirements of international legality. Indeed, there is at least a moral (if not a legal) imperative for a state with the power to intervene against calamitous harms to do so.

The substantive focus of the two analyses is different - Anderson examines what I

failed to fulfil the political, economic or social goals assigned to them', there is no longer any good reason always to insist on the primacy of formal obligations under international law. Why not 'put ... multilateralism in the dock?' he asks. Indeed, why not liberate ourselves from '... the narrow, state-centric choices posited in this symposium, that is, between unilateralism and multilateralism'? Ought we not to give greater attention to ' $\ldots$ other methods for promoting accountability, particularly those involving local institutions or other domestic actors'? Putting to one side his 'straw man' characterization of most international lawyers as multilateralist automatons, the real problem with Alvarez's analysis is its failure to situate the debate about unilateralism in a realistic context. For better or for worse, we live in a world in which governments have, in fact, obligated themselves to abide by multilateral regimes in stipulated contexts. That is why the burden of proof is, and should be, on those who now assert a right to unilateral action which contravenes those commitments. Alvarez's law-as-process understanding of international law moreover leads him to overstate the breadth of the multilateral legal enterprise in order to justify his assessment that it has not worked. To suggest, as he does, that the United Nations can fairly be criticized for having failed to prevent intrastate disputes, mass atrocities or continuing economic disparity between and within nations is simply disingenuous. The governments of the world did not establish a United Nations with the kind of supranational legal authority that would have allowed it to dictate and implement solutions to all these problems. There is certainly no reason to assume that the persistence of these problems proves a failure of multilateralism per se, rather than a failure of will on the part of states meaningfully to commit themselves to meaningful multilateralism.

3 'Convention on the Prohibition of the Use, Stockpiling, Production and Transfer of Anti-Personnel Mines and on Their Destruction', 36 ILM (1997) 1507, entered into force 1 March 1999.

4 Anderson, 'The Ottawa Convention Banning Landmines, the Role of International Non-governmental Organizations, and the Idea of International Civil Society', this issue at 91.

5 Reisman, 'Unilateral Action and the Transformations of the World Constitutive Process: The Special Problem of Humanitarian Intervention', this issue at 3. 
refer to as unilateralism by design, whereas Reisman's most important argument relates to the status of unilateralism by default. It is also striking that whereas Anderson asserts the need for unilateralism in order to counter non-state influences on the development of international law, Reisman relies on non-state processes to establish the law on which unilateral action is predicated. But in at least two ways, the Anderson and Reisman accounts converge.

First, they share a policy-oriented view of the substance of international law. Drawing on the work of Myres McDougal, both Anderson and Reisman assume that international law is not simply an authoritatively sanctioned system of rules and institutions, but is instead comprised of the "whole process of authoritative decision in the world arena ... [including the] whole arsenal of methods and techniques by which policy is projected and implemented'. ${ }^{6}$ As elaborated below, I believe that this perspective fundamentally distorts their analysis. In the case of Anderson, policyoriented thinking suggests an undemocratic intrusion into the international lawmaking process at odds with the historical record; and in the case of Reisman, policy-oriented thinking compels reliance on the wishes of patently unaccountable actors as the source of international legal duties. In short, policy-oriented thinking about international law leads Anderson to misdiagnose the problem, and Reisman to sanction a legally invalid solution.

The Anderson and Reisman accounts are also linked at a more fundamental, and fundamentally disturbing, level. Because they operate within the intellectual rubric of American exceptionalism, neither analysis adequately considers the risks inherent in a validation of increased resort to unilateral action by powerful states. Anderson (explicitly) and Reisman (impliedly) accept the tenability of a situation in which the United States, by virtue of its relative power, is able to determine much of the world public order. I do not.

\section{Anderson on Unilateralism by Design}

Kenneth Anderson examines the failure of the United States to sign on to the Treaty on Anti-Personnel Mines as an example of American determination to act decisively to prevent certain issues of general concern to the majority of the international community from coming under a comprehensive form of multilateral regulation. ${ }^{7} \mathrm{He}$ advances a novel thesis to explain, or at least to justify, the failure of the United States

\footnotetext{
McDougal, 'The Impact of International Law Upon National Law: A Policy-Oriented Perspective', $4 S$. Dak. L. R. (1959) 25, at 36.

7 One answer to Anderson's query, clear from Pierre-Marie Dupuy's opening remarks at the colloquium, is that such a refusal to cooperate may breach a new international duty to cooperate, at least to avoid the use of international force and to promote human rights. See generally Dupuy, 'International Law: Torn between Coexistence, Cooperation and Globalization. General Conclusions', 9 EJIL (1998) 278. While I readily concede the accuracy of Dupuy's argument that there is in fact more cooperation among states in consequence of the homogenizing effect of global capitalism, the case that there is now a duty to cooperate has yet to be made. I agree with Peter Malanczuk that the United States and other governments remain free, as a matter of international law, to withhold their consent to be bound even by treaties of
} 
to sign the landmines treaty. It would be 'a stupidity', ${ }^{8}$ says Anderson, to attribute the American decision to refuse to sign-on to 'arrogance and obduracy'. ${ }^{9}$ To the contrary, the non-participation of the United States in the multilateral effort to ban landmines was justified by the importance of an American stand against 'international legal imperialism'. ${ }^{10}$ While conceding a measure of self-interest in US actions, Anderson insists that there was (and is) a need to save the world from 'the nascent imperialism, the willingness to impose supranational rule, that is the consequence of assertions of the sovereignty of supranational institutions'. ${ }^{11}$

To be clear, Anderson's thesis is not simply that the United States had good reasons not to sign the landmines treaty. ${ }^{12}$ Anderson stakes his claim at a much higher level. The United States was justified in opposing the landmines treaty in order to foil a plot hatched by power-hungry non-governmental activists in cahoots with politically insecure international bureaucrats and petty nations jealous of American political and strategic pre-eminence. America, Anderson suggests, was being held hostage by de facto supranational law masquerading as international law. A stand had to be taken by the United States in defence of the continuing relevance of national sovereignty.

The plausibility of this account of American opposition to the landmines treaty requires acceptance of two assumptions. ${ }^{13}$ First, it must be agreed that the roles played by non-governmental activists are truly part and parcel of the international lawmaking process. Second, even accepting such a characterization, there must be some basis upon which to argue the democratic illegitimacy of their participation.

Anderson is concerned that the presence of non-governmental organizations 'at the negotiating tables, in the halls of power' ${ }^{\prime 4}$ (actually, more commonly in the adjoining hallways, or at best in the observers' gallery) proves that we have moved beyond the era of international lawmaking, and into the realm of supranationalism. Here, it is clear to see that his views are shaped by the policy-oriented perspective on

obvious global importance: Malanczuk, 'The International Criminal Court and Landmines: What are the Consequences of Leaving the US Behind?', this issue. Because unilateralism by design therefore presents no issue of international legality, the issue Anderson invites us to consider is not whether abstention from emerging forms of multilateralism is lawful, but why it occurs.

8 See Anderson, this issue (hereafter Anderson) at 96.

9 See Anderson, at 94.

10 See Anderson, at 97.

11 Ibid.

12 Peter Malanczuk observes, for example, that the United States might reasonably have opposed the landmines treaty for technical reasons, e.g. that it ought to have distinguished between conventional 'dumb' landmines, which remain deadly for the long term, and more recently deployed 'smart' landmines, which can more readily be neutralized or deactivated. It might also simply have justified its position on the grounds that the treaty would interfere with American security commitments, particularly in Korea, and constrain its future military options. As Malanczuk rightly concludes, the United States clearly has the sovereign right to refuse to be bound by an international treaty with which it disagrees.

13 Anderson's thesis is also difficult to accept on purely empirical grounds. At no time did the US government justify its failure to sign the treaty as necessary to vindicate an unsullied understanding of international law as the exclusive product of interstate negotiation, much less as part of some grand effort to revive a world in which international law is minimally intrusive on state sovereign prerogatives.

14 See Anderson, at 111. 
international law which has sought to redefine international law as essentially indistinguishable from the process by which such rules are made. If law is process and unelected non-governmental activists were part of the process, then activists were in fact unelected lawmakers. The landmines treaty is said to be an undemocratic imposition because entities other than states were significantly involved in the process of promoting and defining relevant norms and implementation structures. Desperately seeking a means to rationalize American actions, Anderson invokes policyoriented thinking in order to invent a villain against which the United States could conceivably have been fighting a 'just war'. But in truth, while non-governmental organizations were perhaps granted greater access to the Ottawa conference than to most treaty negotiation sessions, their presence was approved, indeed often encouraged, by governments. There was no hostile takeover of the drafting process. The standards adopted were agreed to by states, and states alone.

Even if one were to embrace Anderson's conflation of process with law, I do not think he has made his case that the role of non-state actors in promoting and developing new law is necessarily politically illegitimate. In seeking to mobilize public opinion to support particular initiatives, non-governmental organizations do no more than orchestrate a collective exercise of free speech. Apart from their ability to stimulate and to focus state attention on issues by the mobilization of public opinion, the role of the non-governmental sector is, at best, auxiliary to that of states. Non-governmental organizations may be allowed to air their concerns, or even to advise governments that choose to listen to them. But I am at a loss to understand why such a role bespeaks any infringement of state sovereignty, much less the fundamental democratic deficit that Anderson decries. ${ }^{15}$ In any event, why would the US government, which condones privately funded political free speech on a scale unknown in the rest of the industrialized world, possibly feel the need to eradicate significantly less well-funded free speech efforts by human rights and other campaigners on the international level?

The decision of many governments that drafted the landmines treaty to involve non-governmental experts in their work actually shows a healthy respect for substantive democracy. If anything is undemocratic, it is the usual practice of government bureaucrats purporting to define a state's position on important international issues without consultation or, at best, by conferring with an elite coterie of professional experts. I agree with Anderson that it is wrong to equate non-governmental organizations with 'civil society'. ${ }^{16}$ But they are a part of civil society that deserves to be heard. That the state representatives assumed by Anderson to be democratically accountable chose to collaborate with non-state actors does not in any meaningful sense challenge the fundamental rule that it is states, and states alone, that must ultimately define the scope of international law.

15 See Anderson, at 115.

16 See Anderson, at 110. 


\section{Reisman on Unilateralism by Default}

Michael Reisman's contribution to the symposium is a stark example of a justification for unilateral action based on McDougal's policy-oriented perspective. Reisman sets a particularly ambitious goal for himself, arguing for a right to undertake unilateral humanitarian intervention when multilateral institutions are found to be inadequate to the task. ${ }^{17}$ Specifically, he contends that states are entitled to breach the United Nations Charter's prohibition of the unilateral use of force because of a new legal imperative. The authority for unilateral intervention emanates from a new form of international decision-making process, which includes:

... not only officials of states, but the aggregate actual decision process, comprised, as it is, of governments, inter-governmental organizations, non-governmental organizations and, in no small measure, the media. All the actors, who assess, retrospectively or prospectively, the lawfulness of international actions and whose consequent reactions shape the flow of events, now constitute, in sum, the international legal decision process. (emphasis added) ${ }^{18}$

Reisman, like Anderson, thus conflates the process by which international law is made with international law itself. By doing so, he is able to see new sources of 'law' which trump established norms and institutions. Because of the 'virtual enfranchisement of the transnational electronic mass media as an independent force largely animated by the values of the Western liberal tradition', ${ }^{19}$ the media's implicit insistence on an international response to 'graphic images of human rights violations' has become imperative and is virtually required by the international legal process of those governments that have the wherewithal to effect it.

On the basis of this kind of reasoning, the decision of the United States to bomb suspected terrorist strongholds in Sudan and Afghanistan was not only not illegal, but was actually required by international law. After all, the Western mass media - in Reisman's view, a newly enfranchised source of international law — insisted upon a strong response to the attacks on US embassies. Similarly, had NATO - even without Security Council authorization — not bombed Kosovo, it would arguably have violated international law, since once again the new media-driven 'international legal process' demanded a response to Serbian atrocities.

Reisman seems quite unconcerned by the fact that the brand of unilateralism he espouses flatly contradicts the United Nations Charter's duty to collectivize the use of force in other than situations of self-defence. He presents the Charter as having been superseded by the imperatives of the amorphous 'decision process' he describes. Because that process - i.e. the constellation of governments, intergovernmental organizations, NGOs, and the Western liberal media - has demanded (at least, as heard and interpreted by powerful states) a more effective mechanism of intervention than that set by the UN Charter, new imperatives will perforce be addressed by unilateral action that the international legal process may deem lawful, even as state

17 See Reisman, this issue (hereafter Reisman), at 16.

18 See Reisman, at 13.

19 Ibid. 
elites that find the new regime threatening protest it. ${ }^{20}$ This summary dismissal of the Charter as elitist, as obviously less democratic than the new 'international legal process' (composed of disproportionately Northern and unelected voices) championed by Reisman, is completely unsubstantiated.

Reisman's account is thus little more than a rationalization for unilateral action by powerful governments, most obviously that of the United States. He redefines law as process, deems the media and other non-state actors to be integral sources of law so defined, and grants those states possessed of 'the wherewithal to effect [intervention] ${ }^{21}$ the prerogative to define what 'law' has been generated by the media and others in that 'lawmaking' process. So long as the resultant intervention is not negatively 'reviewed' by the (mostly unaccountable) actors in the process, the unilateral action is legal. This is so even if the intervention is clearly contrary to the United Nations Charter or other more traditional sources of law. ${ }^{22}$

But even if this amorphous process could generate law, on what basis would that law allow clear rules in the United Nations Charter validly to be ignored? 'A constitution is not a suicide pact', argued Reisman in discussion at the colloquium, relying on a famous quotation (probably inaccurately) attributed to Oliver Wendell Holmes. ${ }^{23}$ Understood in context, this phrase, first invoked by Justice Robert $\mathrm{H}$. Jackson in Terminello v. City of Chicago ${ }^{24}$ and reframed by Justice Arthur Goldberg in

20 Reisman, at 8.

21 See Reisman, at 15.

22 Instead of pretending that process is law, and that powerful states are now 'bound' to act at the behest of some new and unaccountable international decision process, why doesn't Reisman simply argue that the United States (and others) are released from their Charter obligations by virtue of a fundamental change of circumstances? Reisman's point of departure, after all, is that the 'realistic formula' of the United Nations Charter no longer holds because '... participation in the constitutive process expanded and the relative effectiveness of the various categories of participants began to shift in ways quite different from the conceptions of classical international law'. Why not then make the honest case for rebus sic stantibus? And if that is impossible, shouldn't the legal credibility of his account be impugned?

23 Two law review articles attribute this phrase to Holmes: Reisman, 'The Constitutional Crisis in the United Nations', 87 AJIL (1993) 83, at 89; and Dowdle, 'The Constitutional Development and Operations of the National People's Congress', 1 Col. J. Asian L. (1997) 125. Neither provides a citation for the alleged quotation. On the other hand, the phrase is cited in various American judicial decisions, none of which attributes it to Holmes. Of the twenty federal cases that cite the phrase (or a variation of it), fifteen cite either the Terminello or Kennedy case (see notes 12 and 13 infra), while five cite no source.

24337 US 1, 37; 69 S. Ct 894, 911 (1949) (Justice Jackson dissenting). The issue in this case was whether the First Amendment prohibits a city from enacting a breach of peace ordinance that presumes to prevent people from, among other things, making any improper noise, riot, disturbance, breach of the peace, or diversion: ibid. at 3 . The petitioner-defendant gave a speech that was creating a large and hostile audience of more than 1,000 people, giving rise to a disturbance. The majority of the members of the court held that the city ordinance was unconstitutional because its construction was too broad; it would prohibit speech that simply stirred people to anger, invited public dispute, or brought about a condition of unrest: ibid. at 5. The court found that one purpose of free speech was to invite dispute: ibid. Justice Jackson, in dissent, argued that the majority had ignored the conditions under which the petitioner was speaking: ibid. at 13. He characterized the speech as anti-Jewish, fascist, and one that would inevitably lead to outbreaks of violence: ibid. at 36. He concluded his dissent by warning that, "if the Court does not temper its doctrinaire logic with a little practical wisdom, it will convert the constitutional Bill of Rights into a suicide pact': ibid. at 37 . 
Kennedy v. Mendoza-Martinez, ${ }^{25}$ actually suggests a result that is inconsistent with Reisman's argument. Both Justices Jackson and Goldberg relied on the phrase to limit the scope of particularized rights in the interest of promoting the collective welfare. ${ }^{26}$ Reisman's objective, on the other hand, is to expand the unilateral rights of hegemonic states at the expense of the international community's binding commitment to collectivized security.

And in any event, the Charter is not a constitution. It is a treaty, and state parties to treaties undertake a duty to implement their obligations in good faith. ${ }^{27}$ They may not simply walk away from those obligations when their self-interest so inclines them.

\section{May We Speak Frankly?}

My concern with the Anderson and Reisman accounts is both methodological and substantive; indeed, I believe the two concerns are fundamentally connected. While aware of the influence enjoyed by the so-called Yale school of international law on American academic opinion, ${ }^{28}$ I nonetheless feel compelled to challenge it. I do so because I believe that, as a method of identifying 'law', it depletes international law of the certainty required for meaningful accountability. Furthermore, precisely because it generates such imprecise standards, I fear that the policy-oriented approach to international law is too readily exploited by powerful states anxious to disguise their particularist agendas as compelled by, or at least consistent with, international law.

In contrast to Anderson and Reisman, I approach the discussion of unilateralism in international law as a critical positivist. In my view, rules and procedures should generally be said to be part of international law only if they have been explicitly or impliedly consented to by the states said to be bound. While superficially more expansive than the positivist position, the extraordinarily vague and potentially far-reaching nature of the policy-oriented paradigm in practice dissuades govern-

25372 US 144, 160; 83 S. Ct 554, 563 (1963) (Justice Goldberg). In this case, the court held that statutes that divest an American of his or her citizenship for leaving the United States or remaining outside the country during a time of war or national emergency for the purpose of evading conscription are unconstitutional under the procedural safeguards of the Fifth and Sixth Amendments: ibid. at 186. Despite the holding of the court, Justice Goldberg made it clear that Congress has the authority to require military service: ibid. at 159. It was in defence of this proposition that Justice Goldberg observed that ' $[\mathrm{t}]$ he powers of Congress to require military service for the common defense are broad and far-reaching, for which the Constitution protects against invasion of individual rights, it is not a suicide pact': ibid. at 159-160.

26 See ibid.

27 'Every treaty in force is binding upon the parties to it and must be performed by them in good faith': Vienna Convention on the Law of Treaties, UNTS 1155, 331, entered into force 27 January 1988, at Art. 26. The Vienna Convention is generally regarded as a codification of pre-existing customary international law: American Law Institute, 1 Restatement (Third) of the Foreign Relations Law of the United States 145 (1987).

28 Certain non-American commentators, particularly those educated in the United States, have also subscribed to much of the Myres McDougal-inspired thinking on the nature and scope of international law. See e.g. R. Higgins, Problems and Process: International Law and How We Use It (1994). 
ments from treating international law as a meaningful source of real obligations. ${ }^{29}$ Whatever breadth is sacrificed by insistence on evidence of consent is, in my view, more than compensated for by gains in both political legitimacy and meaningful enforceability that accrue from an understanding of international law as a system of consent-based rules and operations.

Stripping the policy-oriented theory of any pretence of political neutrality, Anthony D'Amato argues that international law is composed simply of those norms derived from state practice which facilitate systemic homeostasis or equilibrium. ${ }^{30}$ Law is process, and is therefore essentially indistinguishable from international relations, or even from plain old international politics. As discussions at this symposium have made clear, the inherent ambiguity of policy-oriented definitions provides extraordinary camouflage for the exercise of unilateral action in defiance of norms of unquestioned legal authority. ${ }^{31}$ That is, the murky definitions of international law proposed by Myres McDougal and the generation of legal theorists who followed his lead are not simply harmless efforts to make international law a bit more intellectually exotic. This policy-oriented school of international law is in fact fundamentally anti-democratic.

By rejecting legal positivism, with its concern to limit the scope of international law to those standards agreed by sovereign states to bind them, the policy-oriented perspective on international law facilitates an equation of international law with whatever norms are of value to dominant states. By deeming the process through which norms and institutions are agreed to be as much law as the resultant norms and institutions themselves, and by equating political and economic power with legitimate rule-making authority, the policy-oriented school of international law provides a ready-made justification for defiance of established international norms and procedures by powerful countries. After all, if rules and institutions established by consent are of no more 'law' than is the process of interstate power-brokering and influence, then rules and institutions can freely be ignored when they fail to serve the interests of hegemonic states. The policy-oriented school of international law has thus spawned a new version of natural law thinking under which the wills of powerful states are simply substituted for that of God or nature.

29 Indeed, it has occurred to me that the very fluid, policy-oriented account of international law may have been devised precisely because it imposes so few clear obligations on states. As a response to the traditional isolationism of the United States, a non-threatening understanding of international law may have been thought strategically necessary to induce greater American participation in international legal regimes.

30 D'Amato, 'On the Sources of International Law', paper presented at the University of California at Berkeley, 18 January 1996, at 68: "There are no mysterious "sources" of international law. The rules of international law derive from the behaviour (or practice) of states as they interact with each other within the international system. Both the states, and the system itself, have an overarching goal: to persist through time. Rules of law, accordingly, play a role in facilitating this persistence, primarily by signalling to states a class of prohibited behaviours. If a state ignores a prohibitory rule, it risks creating friction with other states that could lead to a rupture of systemic equilibrium.'

31 See e.g. Wedgwood, 11 EJIL (2000), forthcoming. 
The cases examined by Reisman and Anderson show how policy-oriented understandings of international law are useful to a government that seeks to manipulate the scope of relevant law to coincide with its own preferences. A powerful state committed to avoiding compliance with the duty to refrain from the unilateral use of force pursuant to the UN Charter is, Reisman suggests, entitled to redefine a Western-dominated unofficial network as a source of law. Because powerful states enjoy the right to interpret and act upon the prescriptions of this 'constitutive process', voilà: unilateral intervention in a foreign country called for by the media and other non-state actors is now legal. But what if that same unofficial network suggests the need to rid the world of landmines that kill and maim thousands of innocent civilians every year? No problem, the policy-oriented, law as process school still can help. Because powerful states ('those with the wherewithal' to act $^{32}$ ) remain the final arbiters of the result of the diffuse lawmaking conversation, no action need be taken if the representative legitimacy of the speakers is called into question. In short, the fungibility of policy-oriented views of international law can be manipulated in ways that the fairly clear requirements of legal positivism cannot.

The consent-based understanding of international law embraced by positivists is, of course, not without flaws of its own. It is true that gender and other forms of bias permeate domestic legal systems, and hence limit the extent to which a state's agreement to be bound internationally truly reflects the consent of all of its people. ${ }^{33}$ Yet a consent-based understanding of international law at least ensures that as more socially inclusive understandings of power and politics evolve at the domestic level in an increasing number of states, these automatically impact the international lawmaking process as well (because the consent of these more inclusive systems of governance will be required to create new international law). It is also true that the consent-based foundation of legal positivism is attenuated by its willingness to impose what amounts to a contract of adhesion on new states - those states that wish to be recognized must sign on to the established rules of general international law. ${ }^{34}$ But even this violation of true consent theory is surely a less egregious intrusion on those states' self-determination than is the neo-natural law alternative, which effectively gives powerful states the right to define law not only at the moment of a new state's independence, but indefinitely. In sum, legal positivism's insistence on the consent of states is the least illegitimate basis for a system that purports to govern in the absence of a mechanism for the direct enfranchisement of real people.

This concern about integrity in the definition of international law links to my second, and more fundamental, critique. Neither Anderson nor Reisman is willing to defend American unilateralism on the grounds that the United States simply preferred the pursuit of its national interests to participation in a multilateral process which

32 See Reisman, at 15.

33 Charlesworth, Chinkin and Wright, 'Feminist Approaches to International Law' 85 AJIL (1991) 613.

34 See e.g. Mohammed Bedjaoui, Towards a New International Economic Order (1979) 49 ff. 
constrained its options. ${ }^{35}$ Each seems to feel the need to embroider an elaborate explanation for US unilateralism that is firmly grounded in principle. Specifically, both Anderson and Reisman defend resort to unilateralism on grounds of the need to promote democratic legitimacy. Anderson is concerned to combat 'the empire of international legalism', which lacks the requisite connection with 'actual populations of actual people' needed to be a legitimate source of law. ${ }^{36}$ Reisman's concern to promote democracy plays out in precisely the opposite way. For him, '... the emergence of international legal process ... is, in itself, a triumph of enhanced participation, as it does, many heretofore ineffective international actors with a corresponding reduction in the power of many state elites'. ${ }^{37}$ Yet this superficial difference yields to substantive similarity. Despite the opposite ways in which Anderson and Reisman conceive the democratic deficit of contemporary international law, they assume that unilateral action by powerful states, specifically by the United States, can safely be assumed to promote democracy.

Reisman sees no basis for concern that this diffuse mode of law creation might be looked to as a pretext for self-interested intervention. This is because we can rely on the new participants in the international legal process - that is, the media, non-governmental groups and others - to act as the force that compels and reviews the lawfulness of unilateral acts that purport to be based on humanitarian concerns. ${ }^{38}$ But as Reisman himself acknowledges, the duty to intervene under his paradigm falls to those governments that have the wherewithal to effect it - that is, to the United States and, at least theoretically, other powerful states. The governments of these states, and they alone, decide when to intervene. Governments may, of course, be influenced by the media, non-governmental organizations, business interests, and others. But to suggest that these non-state actors can actually 'appraise ${ }^{39}$ the lawfulness of a decision by a powerful government to intervene in another country is, in other than a purely rhetorical sense, a clearly misleading assertion.

Anderson's faith in the inherent value of unilateralism, at least by the United States, is framed in much more emphatic terms. He argues that the United States, apparently by definition, simply does not act internationally on the basis of purely self-interested

35 While Professor Reisman clearly needed to invent a countervailing source of legal authority to justify his theory of unilateralism by default (since it countenances breaches of the United Nations Charter), the more fascinating question is why Professor Anderson felt comparably compelled. Since the United States clearly had the right to refrain from participation in the landmines treaty, why did Anderson feel driven to pitch the American case at the level of a moral imperative to vindicate democratic legitimacy? US opposition to the landmines treaty could readily be justified on the grounds of concern that the proposed regime would interfere with its security commitments, particularly in Korea, and constrain future American military options. The unwillingness of other states to grant the United States a situation-specific exemption, an extended timeframe for compliance, or an easy way to denounce the treaty left America with a clear choice. The calculus of self-interest seems clearly to have led the US to walk away from the draft treaty as it was obviously entitled to do. Why embellish this account of clearly lawful, if socially regrettable, isolationism?

36 See Anderson, at 114 and 116.

37 See Reiseman, at $17-18$.

38 See Reisman, at 17.

39 Ibid. 
power considerations. He insists that '... the power the United States exercises in the world ... is embedded profoundly in a web of claims to political and moral legitimacy.' US unilateral action '. . . is never the mere exercise of power (emphasis added)'. Indeed:

... anyone imagining that to struggle with US unilateralism, in the name of international legal order or anything else, is merely to struggle with power harbors a serious delusion. The struggle is inevitably as much or more with ideas as with power; surely this is obvious, but it seems sometimes forgotten in the myopia of wishful and self-righteous internationalist thinking. ${ }^{40}$

Inevitable? Obvious? While I have no doubt that the United States does sometimes, perhaps even often, champion important values in its international relations, I am mystified by the claim that American actions abroad are necessarily predicated on the promotion of transcendent moral and political claims.

It is this belief that the United States is somehow always operating on the basis of principle-derived autopilot that links the Anderson and Reisman accounts of justifiable unilateralism. Each manages to rationalize self-interested American unilateralism as a noble act of international leadership. In taking this position, both Reisman and Anderson are operating from squarely within the American exceptionalist tradition. As Deborah Madsen perceptively observes, ‘... the history of America is a history of redemption - of individuals as well as of the nation itself and this commitment to America as an exceptional nation is reflected in the way the lives of public leaders have been written as continuing the spiritual biography of America, as the nation and its people work towards the salvation of humankind' ${ }^{41}$

The power of the mythology of American exceptionalism should not be underestimated. The sense that the United States has a special moral status and mission ${ }^{42}$ has resulted in an intensive engagement by the United States in foreign affairs, predicated on a belief that America has a unique mission to lead the world. ${ }^{43}$ But even as it is a basis for attribution to the United States of a special right to propose rules of international conduct, American exceptional status is also invoked to 'plead the authority of its internal law to mitigate its international legal obligations' ${ }^{44}$ The United States thus simultaneously asserts the right to lead, but also to be exempted from the rules it promotes. While some measure of respect for the constraints of multilateralism may have made practical sense in the context of the Cold War, the Western 'victory' over the Communist world has now liberated the United States to resume its independent and exceptional place in the world. Thus, the United States

40 See Anderson, at 97.

41 D.L. Madsen, American Exceptionalism (1998) 14.

42 Lazos Vargas, 'Deconstructing Homo(geneous) Americanus: The White Ethnic Immigrant Narrative and its Exclusionary Effect', (1998) Tul. L. R. 1493, at 1596, n. 72, citing Yankelovich, 'How Changes in the Economy are Reshaping American Values', in Henry J. Aaron et al. (eds), Values and Public Policy (1994) 23-24.

43 De Santis, 'Mutualism: An American Strategy for the Next Century', 4 World Policy Journal (1998); 1998 WL 15670067 , at 2, 4 .

44 Richardson, 'The Execution of Angel Breard by the United States: Violating an Order of the International Court of Justice', 12 Temp. Int'l. E Comp. L. J. (1998) 121, at 127. 
was not really opposed to the landmines treaty - it simply did not want to be bound by the same standards of obligation imposed on other states. And the United States does not really want to see the UN Charter's commitment to the collectivization of force eradicated - it simply wants to enjoy a special freedom of action free from the constraints that bind others.

American exceptionalism is similarly a useful means to explain US resistance to most of the international human rights project, ${ }^{45}$ as well as to the proposal for an International Criminal Court. Both initiatives are predicated on the subordination of a purely domestic vision of basic values to a collectively defined norm capable of being operationalized in the international arena. Because there is a surprisingly widespread belief in the United States that foundational American values are both immutable, and inherently superior to anything the world has to offer, compromise of this kind is difficult to accept. Indeed, to the extent that American citizens would themselves be subject to such norms - as both international human rights law and the criminal court treaty assume - this absolute and uncritical embrace of US constitutional values virtually compels a refusal to participate in the regime.

Writing in the October 1999 edition of Harper's Magazine, ${ }^{46}$ Daniel Lazare provides a fascinating account of why it is that Americans seem completely unable even to contemplate what to the rest of the world would be a perfectly obvious answer to the conundrum of Americans being routinely slaughtered by other Americans. After conceding that the drafters of the Second Amendment to the US Constitution did, in fact, intend to allow Americans to possess guns as part of the bulwark against the then-credible threat of the resurgence of tyranny, Lazare pointedly asks ' . . why must we subordinate ourselves to a 208-year-old law that ... is contrary to what the democratic majority believes is in its best interest? Why can't we create the kind of society we want as opposed to living with laws meant to create the kind of society they wanted? ${ }^{47}$ The answer, Lazare believes, lies in the near-mythological attachment of Americans to the sacred text of their constitution:

... The Constitution's hold on our society is so complete that it controls the way we discuss and debate, even the way we think. Americans are unable to conceive of an alternative framework, to think 'outside the box', as corporate strategists put it. Other countries are free to change their constitutions when it becomes necessary.... If they can do it, why can't we? Why must Americans remain slaves to the past? ${ }^{48}$

45 'While the United States has been involved in the drafting of every major human rights treaty, is represented at virtually every session of every human rights monitoring body, and annually publishes its assessment of the human rights performance of every country in the world, we simply do not accept that international human rights law is about us. We cannot bring ourselves as a nation to adopt international human rights standards as domestically binding norms, and we certainly will not tolerate other states or international bodies scrutinizing the ways in which human rights are (or are not) implemented in the United States': Hathaway, 'America’s Apostasy', 3 Law Quadrangle Notes (1999) 10-11.

46 Lazare, 'Your Constitution is Killing You', 1793 Harper's Magazine (1999) 57.

47 Ibid. at 65 .

48 Ibid. at 65 . 
This uncritical belief that American constitutional values must never be challenged, that they simply could not be improved and should therefore not be revisited, explains not only America's general reluctance to sign on to human rights treaties, but more specifically why such US accessions as have taken place are always qualified by a reservation that denies any obligations inconsistent with the US Constitution, and also why the United States never allows its own citizens to seek the review of domestic human rights determinations before international bodies.

Against this backdrop of historically anchored moral certitude, multilateralism of a kind that either defines or enforces basic values, like that which constrains America's unique duty to lead the world in political and strategic terms, is simply unacceptable. Because America's foundational values are accepted as inherent truths, there is much to lose and nothing to gain from fulsome participation in key parts of the multilateral international legal order. Sadly, I believe that unilateralism by design of the kind described by Kenneth Anderson may also contribute to the perception that concerns which belong in Michael Reisman's fourth category of international constitutive processes - namely, those clearly subject to multilateral regulation - are, in practice, slipping into his third category of variable multilateral efficacy which, in his view, justifies context-specific unilateralism. The seeming inability of the United Nations to manage even such obviously worthy concerns as the eradication of anti-personnel mines contributes to a growing sense that the United Nations simply cannot be relied upon to solve important international problems. In a beautiful irony, then, unilateralism is vindicated and effective power restored to a nation that bears much of the responsibility for the weakened multilateral enterprise. 